\title{
Postharvest conservation of the tuberous roots of Pachyrhizus Ahipa (Wedd) Parodi
}

\author{
ROSILDA M. MUSSURY ${ }^{1}$, SILVANA P.Q. SCALON ${ }^{1}$, MAGAIVER A. SILVA ${ }^{2}$, \\ TATIANE F. SILVA ${ }^{3}$, HELLEN GOMES ${ }^{4}$ and ROSIMEIRE GASSI ${ }^{4}$ \\ ${ }^{1}$ Universidade Federal da Grande Dourados/ UFGD, Rodovia Dourados/Itahum, Km 12, 79804-970 Dourados, MS, Brasil \\ ${ }^{2}$ Pós-Graduando em Ciências da Saúde, Universidade Federal da Grande Dourados/ UFGD, \\ Rodovia Dourados/Itahum, Km 12, 79804-970 Dourados, MS, Brasil \\ ${ }^{3}$ Pós-Graduando em Engenharia e Ciência de Alimentos, Universidade Estadual de São Paulo, Campus São José do Rio Preto, \\ Rua Cristóvão Colombo, 2265, Jardim Nazareth, 15054-000 São José do Rio Preto, SP, Brasil \\ ${ }^{4}$ Pós-Graduação em Agronomia/Produção Vegetal, Universidade Federal da Grande Dourados/ UFGD, \\ Rodovia Dourados/Itahum, Km 12, 79804-970 Dourados, MS, Brasil
}

Manuscript received on July 12, 2011; accepted for publication on June 4, 2012

\begin{abstract}
This paper aimed to evaluate the effects of storage periods on the conservation of Pachyrhizus ahipa roots at different temperatures and packaging materials. The roots were harvested, washed, packed in PVC, plastic bags, without wrappings (control) and stored in polystyrene trays in refrigerators, or cold chambers, or at room temperature. Total titratable acidity (TTA), total soluble solids (TSS), pH, as well as their ash, lipid, total carbohydrate and protein (dry basis) contents were analyzed. The lowest loss of root fresh weight was observed in the cold chamber and plastic bags. The TTA remained higher among roots stored in the cold chamber and in PVC packaging. The lowest TSS contents were observed for roots stored in the cold chamber, and these did not vary among the packing materials. The average carbohydrate content percentage for all treatments was $84.9 \%$. The percentage of lipids was highest in roots stored at room temperature while protein and ash contents were highest in roots under refrigeration. The best storage conditions for roots are plastic bags packaging in a cold chamber, with the roots retaining appropriate quality for commercialization for up to 30 days.
\end{abstract}

Key words: yam bean, storage conditions, packaging, preservation.

\section{INTRODUCTION}

Pachyrhizus is one of the few legume genera that have edible tuberous roots with high nutritional value and a potential for large-scale cultivation (e.g. P. erosus (L.) Urban, P. tuberosus (Lam.) Sprengel and P. ahipa (Wedd.)) (Kay 1973, Sorensen et al. 1997). One of the main reasons for the increased

Correspondence to: Silvana de Paula Quintão Scalon

E-mail: silvanascalon@ufgd.edu.br interest in this species is its high amylopectin content, that making Andean "yam bean" ideal for the starch industry. Additionally, the protein content of the tuberous roots of P. ahipa has also stimulated commercial interest in this product, and it is highly appreciated in Europe (Sorensen et al. 1997).

Economic interest in Pachyrhizus in Mato Grosso do Sul State (Brazil) is focused on the high 
starch content of its roots, which has stimulated its cultivation and consumption and contributed to the sustainable development of domestic agriculture. However, the quality of the roots must be taken into consideration for both commercialization and consumption.

Postharvest losses in Brazil for roots, rhizomes, and tubers have been estimated at $30.3 \%$, and are generally caused by inadequate handling and storage, inappropriate packaging, and pathogens (Chitarra and Chitarra 2005, Cenci 2006). Fresh weight losses of agricultural products result in size loses, wilting, as well as alterations of the food's texture, appearance, and nutritional quality, thus reducing their market acceptance (Woods 1990). Modifications of the gaseous components of the storage air can complement or even replace refrigeration, and this has become an increasingly popular technique for conserving fruits and vegetables (Chitarra and Chitarra 2005). As such, the present work evaluated the efficiency of different storage temperatures and different types of packaging on the post-harvest conservation of $P$. ahipa "jacatupé” roots.

\section{MATERIALS AND METHODS}

Seeds of Pachyrhizus ahipa were sowed in Dourados, Mato Grosso do Sul State (22 $51^{\prime}$ 'S x $48^{\circ} 25^{\prime} \mathrm{W}$; altitude $780 \mathrm{~m}$ ) in December 2006. In August 2007, when the roots were harvested.

Five hundred $P$. ahipa seeds were sowed into plastic planting sacks containing sand and soil (1:1) under uncontrolled environmental conditions in a greenhouse with $50 \%$ full sunlight and daily watering; after 20 days they were transferred to planting beds to complete their development.

After eight months of cultivation, the "jacatupé" roots were harvested, washed under running water to remove any soil particles and were analyzed for their chemical constituents and stored in $25 \times 15 \mathrm{~cm}$ polystyrene trays. The trays, each with $60 \mathrm{~g}$ of roots, were stored in a refrigerator $\left(13^{\circ} \mathrm{C} \pm 2^{\circ} \mathrm{C}\right.$ and $\left.41 \% \mathrm{RH}\right)$, in a cold chamber $\left(5^{\circ} \pm 2^{\circ} \mathrm{C}\right.$ and $\left.70 \% \mathrm{RH}\right)$, or at room temperature $\left(30^{\circ}\right.$ $\pm 2{ }^{\circ} \mathrm{C}$ and $89 \% \mathrm{RH}$ ). Three packaging techniques were used: laminated PVC (polyvinyl chloride) packages; low-density (PEBD) commercial plastic bags (20 $\mu \mathrm{m}$ of thickness); as well as open trays (without packing), as control treatments (Fig. 1).
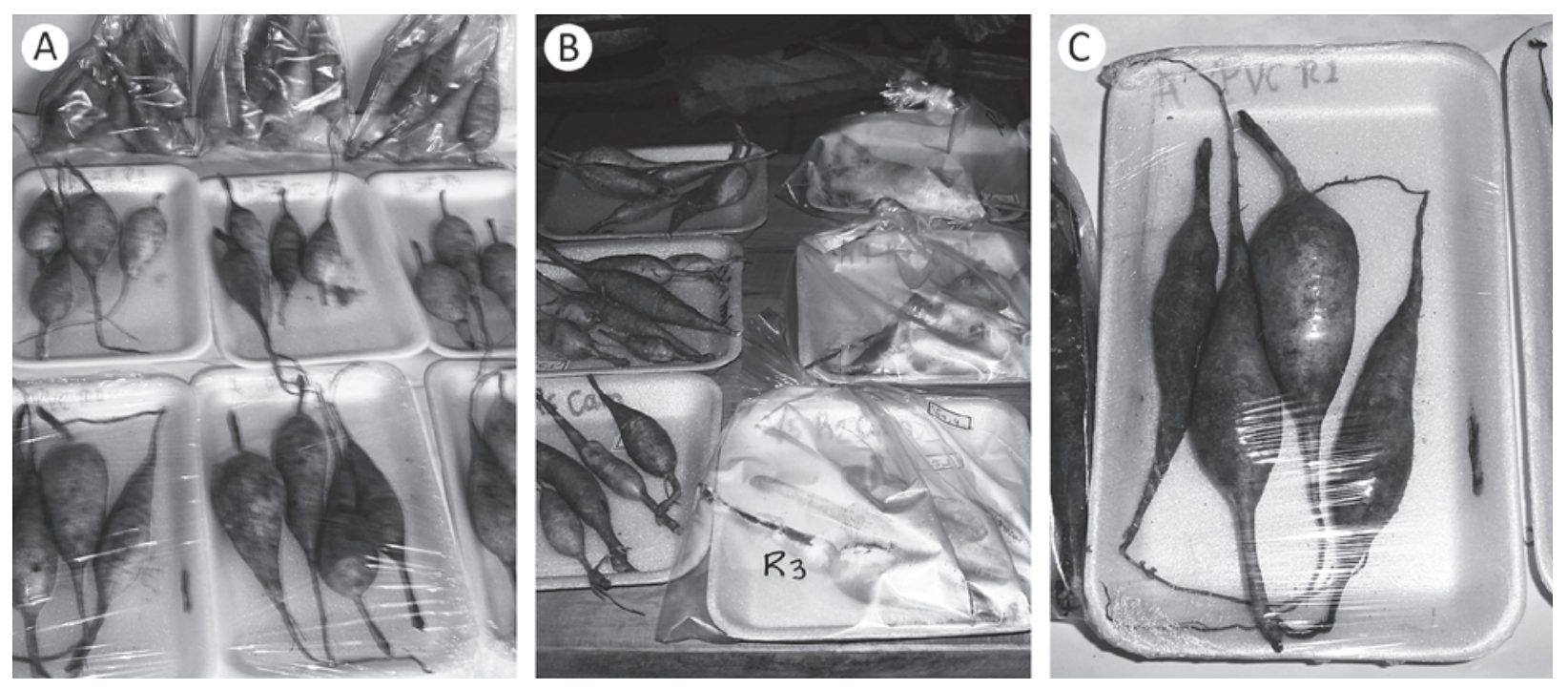

Figure 1 - Jacatupé roots, stored at room temperature (a), in cold chamber (b) and in a refrigerator (c) for 30 days, non-packed, packed with PVC and plastic bag. 
The samples were weighed every two days to determine fresh weight losses. After 30 days, when the roots were wilted and showed evidence of sprouting (characteristics that would make them unacceptable for commercialization), the experiments were terminated and samples were taken for biochemical analyses. At the end of the experimental period samples from each storage condition were submitted to biochemical analyses to determine the average values and standard deviation of the following chemical constituents: water content (by drying at $105^{\circ} \mathrm{C}$ ); proteins (Micro-Kjeldahl method); lipids (acid hydrolyses, followed by Soxhlet extraction using petroleum ether as the solvent); ashes (obtained by incineration, followed by the heating in muffle at 550-570 ${ }^{\circ} \mathrm{C}$ ), according to Adolfo Lutz Institute's methods (1985). The analysis of total soluble solid content (TSS); total titratable acidity (TTA); $\mathrm{pH}$; total sugar content are all according to AOAC (2005)'s patterns; and starch content (according to Dalqvist 1967). The nutritional fiber content was quantified using the enzymatic-gravimetric technique described by AOAC (2005).

The experiment was carried out with a completely randomized block design with 3 replications, of 3 (temperatures) $\times 3$ (packages) factorial arrangement and each experimental unit with $60 \mathrm{~g}$. Three of them were used for weighting and the other three, for biochemical analysis.

The data relating to fresh weight loss were submitted to variance and regression analysis (Banzato and Kronka 2006) and the averages were compared using the Tukey test at a 5\% level of probability, using the SANEST program.

\section{RESULTS AND DISCUSSION}

The roots of "jacatupé" that were collected after eight months of cultivation in Mato Grosso do Sul State (MS) were much smaller than those normally harvested in São Paulo State (where their growth cycle is five months), probably due to variations in the regional climatic and soil conditions. It is therefore suggested that "jacatupé" roots should be cultivated for more than 8 months in Mato Grosso do Sul State to achieve ideal size for commercialization.

The chemical characteristics of $P$. ahipa roots after harvesting are listed in Table I.

TABLE I

Characterization of $\boldsymbol{P}$. ahipa roots soon after the harvest.

\begin{tabular}{lc}
\hline Characteristic & Mean \\
\hline TSS $\left({ }^{\circ}\right.$ Brix $)$ & 6.9 \\
TTA (\% of citric acid) & 0.22 \\
pH & 6.08 \\
Humidity (\%) & 90.84 \\
Ashes (\%) & 3.97 \\
Lipids (\%) & 0.44 \\
Proteins (\%) & 11.57 \\
Carbohydrates $(\%)$ & 84.02 \\
\hline
\end{tabular}

No significant relationships were observed between the packaging materials and storage environments for any characteristics evaluated. Fresh weight losses during storage at room temperature and under refrigeration were considerably higher in roots that were not packaged, followed by roots packaged with PVC, and plastic bags (Figs. 2a and 2b). The lowest fresh weight losses were consistently observed among roots stored in a cold chamber and packaged in plastic bags, leaving the roots with a good appearance and without signs of wilting after up to 30 days of storage.

Fresh weight losses were higher under uncontrolled environmental conditions (47.7\%), followed by refrigeration (38.1\%) and storaged in the cold chamber (31.35\%), with wilting signs seen after 14 days of storaged. Roots stored without any packaging showed high fresh weight (water) losses of up to $84 \%$ by the end of the experiment. Water loss by storage organs is directly influenced by their surface/volume ratios and by the water pressure deficit between the plant organ and outside atmosphere (Finger and Vieira 1997). The PVC film 
reduced the water vapor gradient and consequently diminished root water loss (Ribeiro et al. 2007).

The responses of the roots and tubers of different species to storage at similar temperatures using similar packaging materials were similar to those seen here with P. ahipa (Scalon et al. 2000, 2002, Ribeiro et al. 2007) . Variations in the shelf life of tuberous roots are related to the types of packaging and their storage environment, but the literature consistently confirms that wellpackaged roots can be stored under refrigeration $\left(13 \pm 2{ }^{\circ} \mathrm{C}\right)$ for long periods of time and still retain commercial quality (Tessarioli Neto et al. 1998, Scalon et al. 2000, 2002, Oliveira et al.

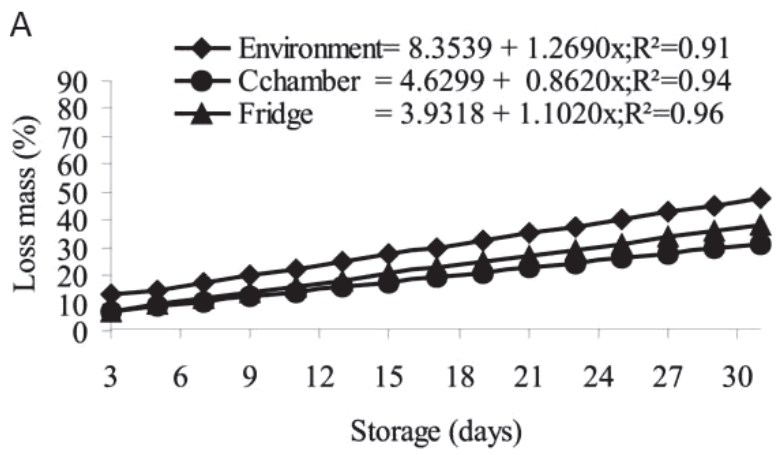

2001, Ribeiro et al. 2007). However, López et al. (2010), while evaluating the productivity and the conditions of post harvest management from P. ahipa roots cultivated in Misiones, Argentina, verified that the storage at $25^{\circ} \mathrm{C}$ was better that under refrigeration. This variation observed by the authors may be attributed to the cultivation conditions. The room temperature used in this research is higher than the temperature one observed for the Misiones region, since it is one of the most humid province of the country and these factors may probably have favoured the root development and consequently, modified the aspects of post harvest conservation.

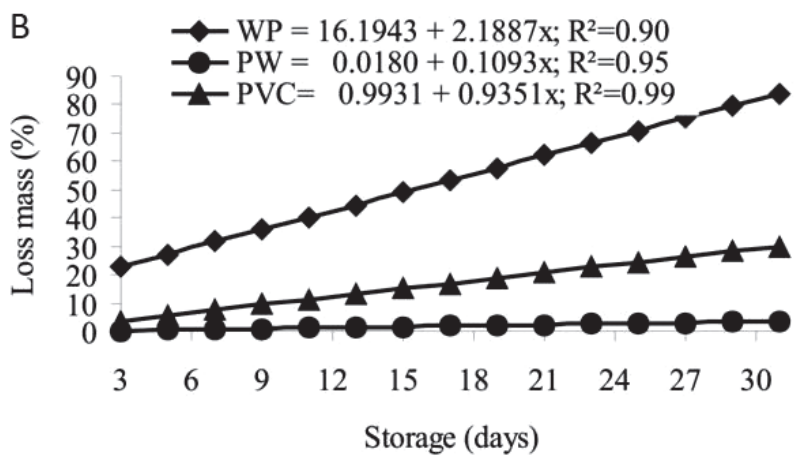

Figure 2 - Mass loss of $P$. ahipa stored in different environments (a). Mass loss on polystyrene trays without package (WP), on trays packed with commercial plastic bag (PW) and with sealed PVC (b).

Scalon et al. (2000) observed that beet roots stored at room temperature without any packaging and under temperatures varying from 15 to $26^{\circ} \mathrm{C}$ became unfit for commercialization after 14 days due to wilting and fresh weight losses $(55 \%)$ beets packaged in PVC film, retained good appearances for 22 days under storage, with average weight losses of only $15.82 \%$ (six to nine times lower than the unpackaged roots); the largest roots showed smaller losses. Tessarioli Neto et al. (1998) likewise noted that beet roots wilted and sprouted after 12 days of storage in polyethylene packages, while roots packaged in PVC and perforated polyethylene showed no sprouting and their fresh weight losses varied from 2.72 to $4.51 \%$.
Scalon et al. (2002) noted that Arracacia roots stored for four days at room temperature were no longer fit for commercialization, while roots stored without any packaging but held under refrigeration lasted 42 days. Packaging and refrigeration together maintained postharvest quality of Arracacia for up to 112 days.

Although both PVC and plastic bag packaging of "jacatupé" roots held in refrigerators and in cold chambers avoided excessive fresh-weight losses, signs of contamination were observed by the $30^{\text {th }}$ day. It was noted that PVC and plastic bag packaging resulted in a high incidence of root decay caused by fungi of the genus Aspergillus. According to Oliveira et al. (2001) packaging 
kept carrots firm during storage by reducing water losses, but favored fungal growth (Aspergillus and Fusarium) and sprouting.

After 30 days, the average data of the TTA of "jacatupé" roots remained higher in roots stored in the refrigerator and packed in plastic bags $(2 \%)$ (Fig. 3a). At room temperature, the lowest average TTA values were observed in roots without any packaging $(0.83 \%$ ) (Fig. 3b), while the lowest TTA values were seen in roots stored in the cold chamber and packaged in PVC (2.1\%) (Fig. 3c).

The root $\mathrm{pH}$ of "jacatupé" increased during storage with all treatments (Figs. 3d, e, f) (initial value 6.08) (Table I), except among roots stored at room temperature and in plastic bags (5.8). However, $\mathrm{pH}$ trends ran contrary to TTA data at all storage temperatures. The soluble solid contents of the roots stored in the refrigerator (Fig. $3 \mathrm{~g}$ ) was similar to the initial value (6.9) (Table I), although roots stored at room temperature and without any packaging (Fig. 3h), as well as those stored in the cold chamber, had the lowest TSS values (Fig. 3i). The literature reports variable root and tuber responses to different storage conditions. Storing carrots at low temperatures stimulates increases in hexose and reductions in sucrose concentrations (Suojala 2000); potatoes stored at temperatures lower than $10^{\circ} \mathrm{C}$ are susceptible to sweetening through increased starch degradation and sucrose accumulation, and principally through increases in glucose and fructose levels (Blenkinsop et al. 2003, Kumar et al. 2004).
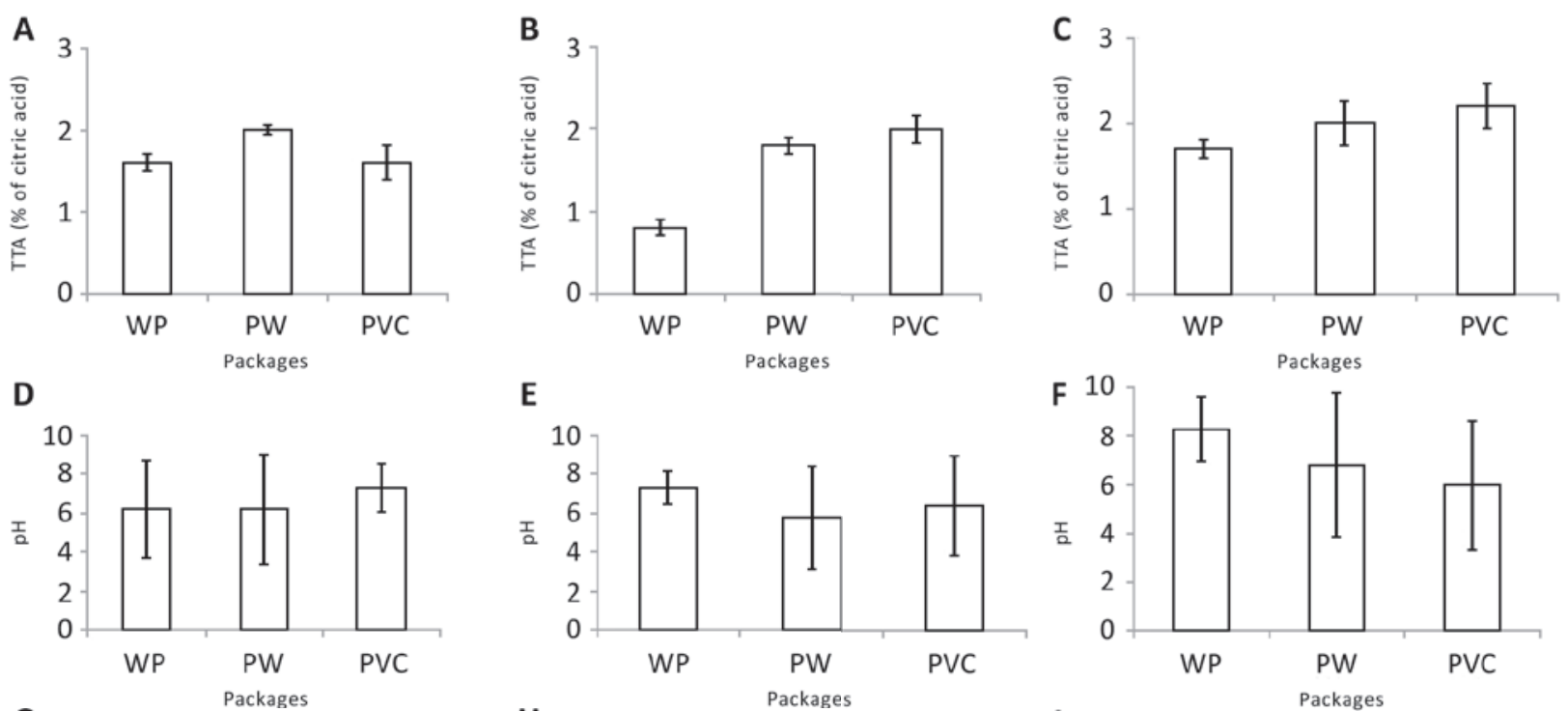

E
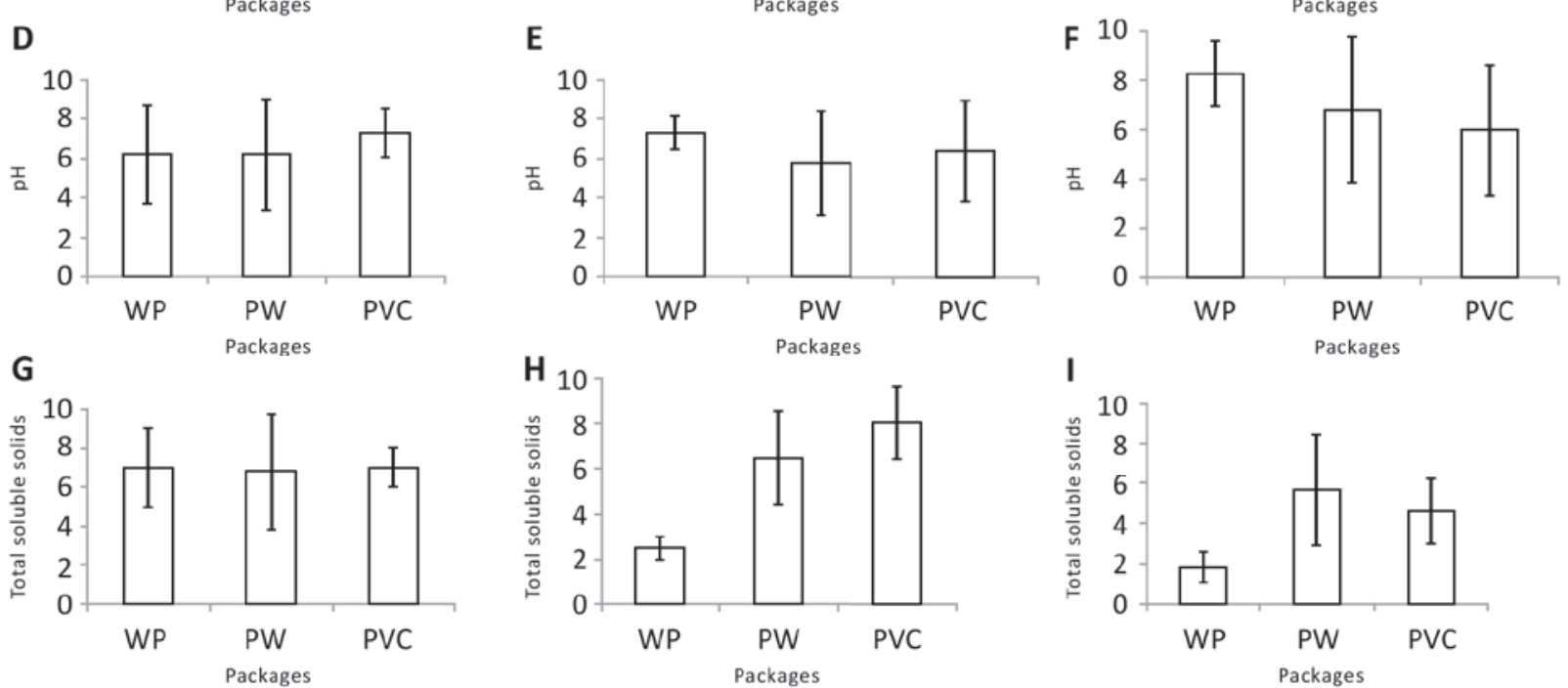

Figure 3 - Total titratable acidity (TTA), pH, total soluble solids of $P$. ahipa stored for 30 days on polystyrene trays without package (WP), in commercial plastic bag and on trays packed with sealed PVC, in fridge (A, D, G), at room temperature $(\mathbf{B}, \mathbf{E}, \mathbf{H})$ and cold chamber $(\mathbf{C}, \mathbf{F}, \mathbf{I})$. UFGD, Dourados-MS. 
Although the individual titers of fructose, glucose and sucrose were not quantified in "jacatupé", their carbohydrate contents remained constant under all storage treatments; while their TSS values diminished with increasingly colder storage temperatures.

The mean carbohydrate percentages were high in all treatments, (84.9\%) (Figs. 4a, b, c). Lipid percentages were higher for roots stored under environmental conditions $(0.29 \%)$ - probably due to higher water losses that concentrated these compounds. Protein (15.3\%) and ash (6.3\%) contents were observed to decrease under all treatments, although they remained higher among roots held in the refrigerator (Figs. 4d, e, f).

In literature, it is observed that a variation on the percentage of the compounds contents in the species may occur, as Zanklan et al. (2007) while evaluating the three species of Pachyrizus (P. tuberosus, $P$. erosus and $P$. ahipa) cultivated in western Africa verified that all the species presented a medium content of proteins, from $5.5 \%$ to $58.5 \%$ starch.

Forsyth and Shewry (2002) in P. ahipa roots found $4.8 \%$ to $8.4 \%$ of raw protein and Leidi et al. (2003) observed the starch content varied from 38.6\% to $54.4 \%$ and from sugar, from $21.8 \%$ to $51.4 \%$.

The chemical compositions of roots are characteristic of each species, and will vary with age, environmental and genetic factors (Ceni et al. 2009), the period of cultivation and harvest, the weather, as well as postharvest temperatures (Seminario et al. 2003). Ceni et al. (2009), observed that climatic conditions during the development of cassava roots (as well as during the post harvest period) can affect their quality and suggested that these environmental factors influenced the physiological processes of growth, accumulation, and mobilization of reserve substances in the tuberous roots of this plant and therefore affected root composition and quality (especially if it is cooked). Thus, as it was necessary to let the "jacatupé" roots grow for longer periods of time
(8 months) in Mato Grosso do Sul State in order to attain commercial dimensions, changes in their nutrient composition would be expected.

Considering costs, benefits and practicality, the use of plastic bags represents the best option for conserving "jacatupé" roots as compared to PVC sacks.

\section{ACKNOWLEDGMENTS}

The authors thank to Conselho Nacional de Desenvolvimento Científico e Tecnológico (CNPq) and to Fundação de Apoio ao Desenvolvimento do Ensino, Ciência e Tecnologia do Estado de Mato Grosso do Sul (FUNDECT), for the financial support and the scholarships.

\section{RESUMO}

O objetivo deste trabalho foi avaliar o período de armazenamento em diferentes temperaturas e embalagens na conservação das raízes de Pachyrhizus ahipa. As raízes foram colhidas, lavadas e armazenadas em bandejas de isopor, no refrigerador, câmara fria e à temperatura ambiente. As embalagens utilizadas foram PVC, saco plástico e sem embalagem (controle). As bandejas foram retiradas do seu ambiente de armazenamento e analisadas quanto a acidez total titulável, sólidos solúveis totais, $\mathrm{pH}$, teores de cinzas, lipídios, carboidrato total e proteínas em base seca. A menor perda de massa das raízes foi em câmara fria e em saco plástico. A ATT manteve-se maior nas raízes armazenadas em câmara fria e na embalagem de PVC; os menores teores de SST foram observados em câmara fria não variando entre as embalagens. Em todos os tratamentos a porcentagem média de carboidratos foi $84,9 \%$. A porcentagem de lipídios foi maior nas raízes armazenadas em temperatura ambiente, entretanto, o teor de proteína e cinzas foram maiores nas armazenadas na geladeira. A melhor condição para o armazenamento das raízes é em câmara fria e embaladas com saco plástico, onde as raízes mantiveram a qualidade apropriada para comercialização durante até 30 dias de armazenamento.

Palavras-chave: jacatupé, condições de armazenamento, embalagens, conservação. 
A
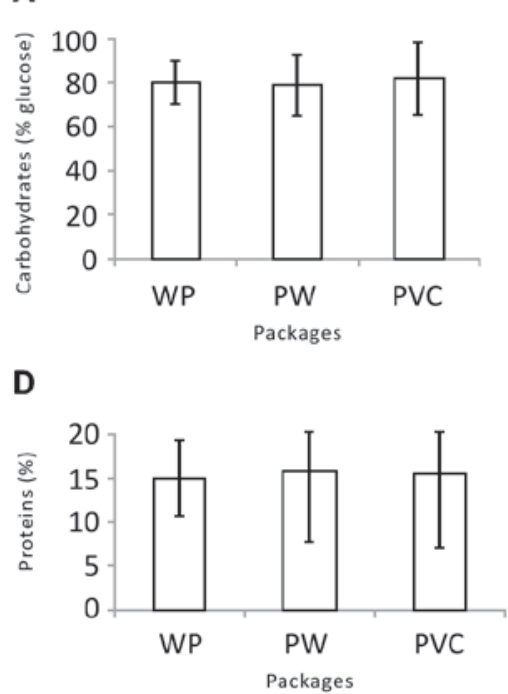

G

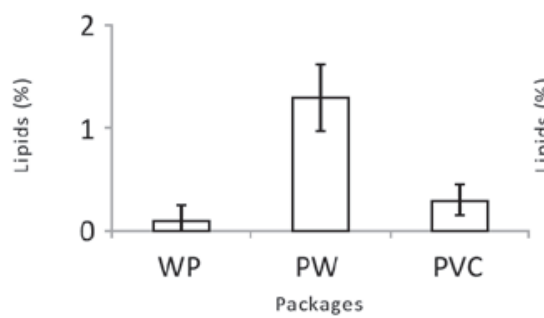

J

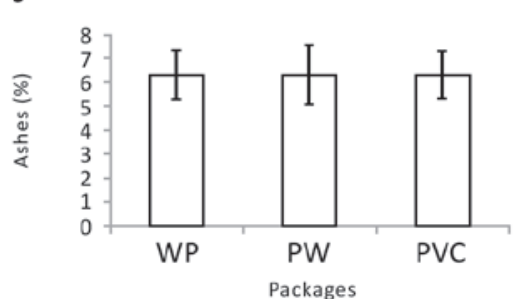

B

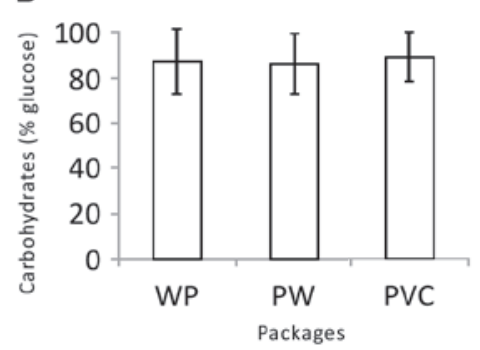

E

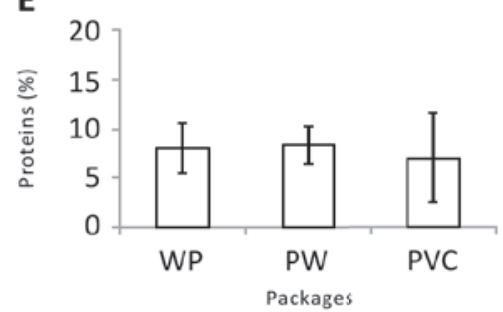

H

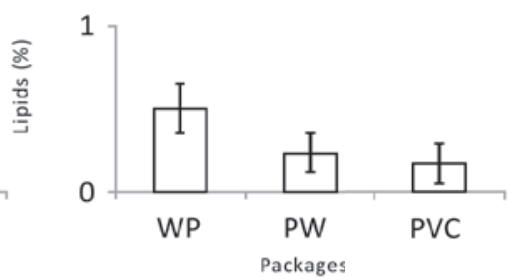

K

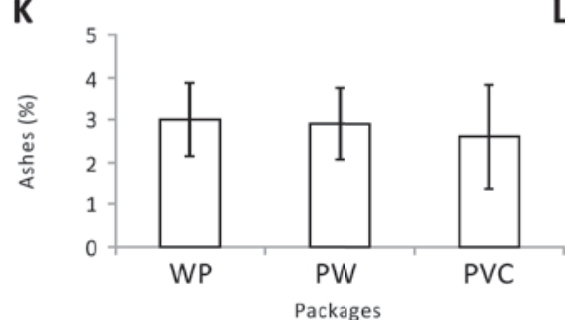

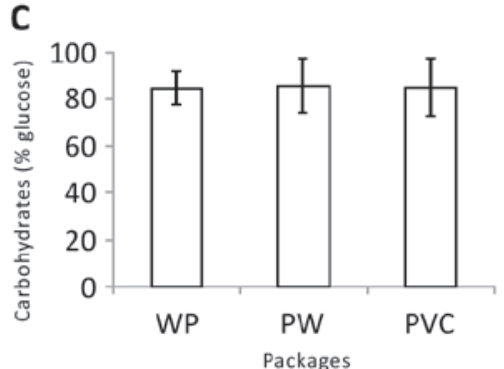

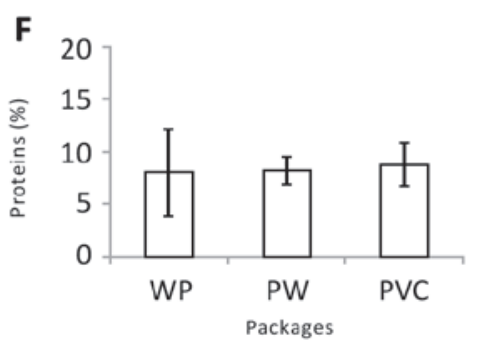

I

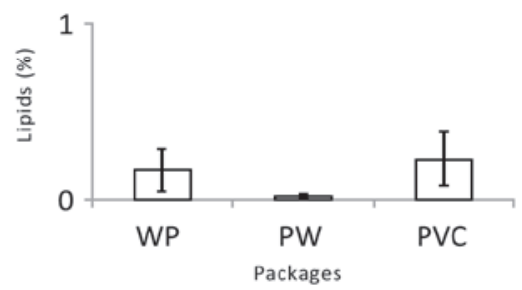

L

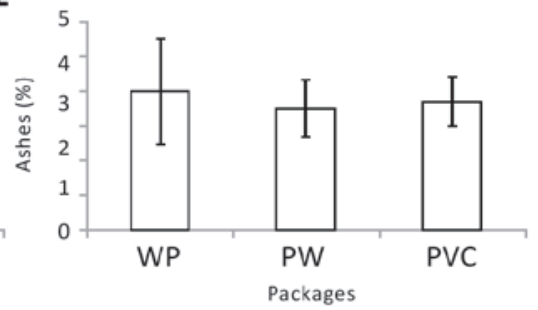

Figure 4 - Mean value of carbohydrates, proteins, lipids and ashes from $P$. ahipa stored for 30 days polystyrene trays without package (WP), in commercial plastic bag and on trays packed with sealed PVC, in fridge (A, D, G, J), at room temperature (B, E, $\mathbf{H}, \mathbf{K})$ and cold chamber $(\mathbf{C}, \mathbf{F}, \mathbf{I}, \mathbf{L})$. UFGD, Dourados-MS.

\section{REFERENCES}

AOAC - AsSOCIATION OF OfFicial ANALYTICAL CHEMISTS INTERNATIONAL [AOAC]. 2005. Official Methods of Analysis. $18^{\text {th }}$ ed., AOAC, Gaithersburg, MD, USA.

BANZATO DA AND KRONKA SN. 2006. Experimentação agrícola. $4^{a}$ ed., FUNEP, Jaboticabal, SP, Brasil.

BLENKInsop RW, Copp LJ, YADA RY AND MARANGONI AG. 2003. A proposed role for the anaerobic pathway during low-temperature sweetening in tubers of Solanum tuberosum. Physiol Plantarum 118: 206-212.
CENCI SA. 2006. Boas Práticas de Pós-colheita de Frutas e Hortaliças na Agricultura Familiar. In: Neto FN (Org), Recomendações Básicas para a Aplicação das Boas Práticas Agropecuárias e de Fabricação na Agricultura Familiar. $1^{\mathrm{a}}$ ed., Brasília: Embrapa Informação Tecnológica, p. $67-80$.

Ceni GC, Colet R, Peruzzolo M, Witschinski F, TOMicki L, Barriquello AL AND VAlduga E. 2009. Avaliação de componentes nutricionais de cultivares de mandioca (manihot sculenta crantz). Alimentos e Nutrição 20: 107-111. 
Chitarra MIF And Chitarra AB. 2005. Pós-colheita de frutas e hortaliças: Fisiologia e manuseio. Lavras, 785 p. Dalqvist A. 1967. Assay of intestinal disacaridases. Analytical Biochemistry, New York 22: 99-107.

FINGER FL AND VIEIRA G. 1997. Controle da perda póscolheita de água em produtos hortícolas. Viçosa: UFV, 29 p. (Cadernos didáticos, 19).

FORSYTH JL AND SHEWRY PR. 2002. Characterization of the Major Proteins of Tubers of Yam Bean (Pachyrhizus ahipa). J Agric Food Chem 50: 1939-1944.

Instituto AdOLFo Lutz. 1985. Analytical standards: chemical and physical methods for analysis of foods. $3^{\text {rd }}$ ed., São Paulo 1: 533. (in Portuguese).

KAY DE. 1973. Yam bean, potato bean. In Root crops (Kay DE (Ed)), Tropical Products Institute, p. 240-245.

Kumar D, Singh BP AND Kumar P. 2004. An overview of the factors affecting sugar content of potatoes. Ann Appl Biol 145: 247-256.

LEIDI EO, SARMIENTO R AND RODRÍGUEZ-NAVARRO DN. 2003. Ahipa (Pachyrhizus ahipa [Wedd.] Parodi): an alternative legume crop for sustainable production of starch, oil and protein. Ind Crop Prod 17: 27-37.

LÓPEZ OV, VIÑA SZ, PACHAS ANA, SISTERNA MN, ROHATSCH PH, Mugridge A, FASSOla HE AND García MA. 2010. Composition and food properties of Pachyrhizus ahipa roots and starch. Int J Food Sci Tech 45: 223-233.

Oliveira VR, Gianasi L, Mascarenhas MHT, PIRES NM AND ViANA MCM. 2001. Embalagem de raízes de cenoura 'brasília' em filme de PVC. Ciênc Agrotec 25: 1321-1329.

Ribeiro RA, Finger FL, Puiatti ME And CASAli VWD. 2007. Vida útil e metabolismo de carboidratos em raízes de mandioquinha-salsa sob refrigeração e filme de PVC. Pesq Agropec Bras 42: 453-458.
SCAlON SPQ, ScAlon Filho H, SANDre TA, Silva EF AND KREWER ECD. 2000. Quality evaluation and sugar beet postharvest conservation under modified atmosphere. Braz Arch Biol Technol 43: 181-184.

SCALON SPQ, ZÁRATE NAH AND VIEIRA MC. 2002. Embalagem e temperatura na manutenção da qualidade póscolheita de mandioquinha-salsa. Ciênc Agrotec 26: 559-563.

SEMINARIO J, VALdERrama M AND MANRIQUe I. 2003. El yacon: fundamentos para el aprovechamiento de un recurso promisorio. Lima, Peru: Centro Internacional de la Papa (CIP), Universidad Nacional de Cajamarca, Agencia Suiza para el Desarrollo y la Cooperación (COSUDE), 60 p.

Sorensen M, Gruneberg WJ And Orting B. 1997. Ahipa (Pachyrhizus ahipa (Wedd.) Parodi). In: Herman M and Heller J (Eds), Andean roots and tubers: Ahipa, arracacha, maca and yacon. Promoting the conservation and use of underutilized and neglected crops. Rome: International Plant Genetic Resources Institute cap. 2, p. 75-172.

SuOJALA T. 2000. Variation in sugar content and composition of carrot storage roots at harvest and during storage. Sci Hortic 85: 1-19.

Tessarioli Neto J, Kluge RA, JACOMINO AP, ScARPare FILHO JA AND IWATA AY. 1998. Conservação de raízes de beterraba"early wonder" em diferentes tipos de embalagens. Hortic Bras 16: 7-10.

Woods JL. 1990. Moisture loss from fruits and vegetables. Postharvest news and information 1: 195-199.

Zanklan AS, Ahouangonou S, Becker HC, PAWElzIK E AND GRÜNEBERG W. 2007. Evaluation of the storage rootforming legume yam bean (Pachyrhizus spp.) under West African conditions. Crop Sci 47: 1-14. 